University of Nebraska - Lincoln

DigitalCommons@University of Nebraska - Lincoln

USDA Forest Service / UNL Faculty Publications U.S. Department of Agriculture: Forest Service -National Agroforestry Center

March 2008

\title{
Filling the gap: improving estimates of working tree resources in agricultural landscapes
}

\author{
C. H. Perry \\ USDA Forest Service
}

C. W. Woodall

USDA Forest Service

G. C. Liknes

USDA Forest Service

Michele M. Schoeneberger

University of Nebraska - Lincoln, mschoeneberger1@unl.edu

Follow this and additional works at: https://digitalcommons.unl.edu/usdafsfacpub

Part of the Forest Sciences Commons

Perry, C. H.; Woodall, C. W.; Liknes, G. C.; and Schoeneberger, Michele M., "Filling the gap: improving estimates of working tree resources in agricultural landscapes" (2008). USDA Forest Service / UNL Faculty Publications. 1.

https://digitalcommons.unl.edu/usdafsfacpub/1

This Article is brought to you for free and open access by the U.S. Department of Agriculture: Forest Service -National Agroforestry Center at DigitalCommons@University of Nebraska - Lincoln. It has been accepted for inclusion in USDA Forest Service / UNL Faculty Publications by an authorized administrator of DigitalCommons@University of Nebraska - Lincoln. 


\title{
Filling the gap: improving estimates of working tree resources in agricultural landscapes
}

\author{
C. H. Perry • C. W. Woodall · G. C. Liknes • \\ M. M. Schoeneberger
}

\begin{abstract}
Agroforestry plantings and other trees intentionally established in rural and urban areas are emerging as innovative management options for addressing resource issues and achieving landscapelevel goals. An understanding of the ecosystem services contributed by these and future plantings would provide critical information to policy and program developers, and a comprehensive inventory would contribute to estimating the cumulative effects of these plantings. Trees used in these practices are not explicitly inventoried by the primary national forest resource inventory of the United States: the Forest Inventory and Analysis (FIA) program of the USDA Forest Service. The FIA program currently limits its inventories to trees in forests meeting specific size and density criteria, but the draft FIA Strategic Plan suggests the addition of an "other treed land inventory" (excluding urban forests). In this study, we use FIA data to estimate the agroforestry and other tree resources of the Midwest and document some obstacles to effective inventories of agroforestry practices. We compare our estimates of forestland area in the Midwest to those derived from
\end{abstract}

C. H. Perry $(\bowtie) \cdot$ C. W. Woodall · G. C. Liknes USDA Forest Service, Northern Research Station, 1992 Folwell Avenue, St. Paul, MN 55108, USA

e-mail: charleshperry@fs.fed.us

M. M. Schoeneberger

USDA Forest Service, National Agroforestry Center, Lincoln, NE, USA
MODIS (MODerate Resolution Imaging Spectroradiometer) Vegetative Continuous Fields (VCF). The differences between these two estimates, particularly in sparsely forested states, support the idea that the expansion of the FIA program to an all-tree inventory would fill an important gap. We propose minor modifications to the inventory that would lead to an improved assessment of agroforestry and other tree resources and practices.

Keywords Inventory - Land use . Monitoring · Natural resources · Policy

\section{Introduction}

What are working trees?

Working trees are those intentionally established in rural and urban landscapes to achieve specific functions. Agroforestry is the use of working trees for agriculture and is distinguished from traditional forestry by having closely associated agricultural or forage production (USDA Natural Resources Conservation Service 1996). Agroforestry includes a number of practices: field, farmstead and livestock windbreaks; riparian forest buffers; silvopasture systems; alley cropping; forest farming; and a variety of special applications to help address natural resource issues such as waste management and wildlife habitat. Christmas trees and nut/fruit 
orchards generally are excluded from the definition. Specific details are available from the USDA National Agroforestry Center (http://www.unl.edu/nac/).

Working tree plantings are deliberately composed, arranged, and managed to enhance or restore key ecological services that society deems valuable ( http://www.unl.edu/nac/workingtrees.htm). These services range from maintaining air, water and soil quality to enhancing crop productivity, conserving energy, and diversifying income (see other papers in this special edition). A linked system of upland and riparian buffers, in conjunction with other conservation practices, can restore many ecological and economic functions while fostering community among watershed residents and landowners (National Research Council 1993; Schoeneberger et al. 2001; National Research Council 2002; USDA National Agroforestry Center 2004). By increasing structural diversity in landscapes, working trees have ecologic impacts far beyond the proportion of land they occupy and provide opportunities to integrate productivity and profitability with environmental stewardship (Guo 2000; Olson et al. 2000). One indirect benefit from these relatively small, fragmented plantings is the mitigation of greenhouse gas emissions and the sequestration of carbon at regional and national scales while the bulk of the land remains in its original working land use (Schoeneberger 2005).

Which programs promote working tree practices?

Some conservation programs promote the use of working tree practices by providing financial incentives to landowners to establish and manage these plantings. The Farm Security and Rural Investment Act of 2002 increased financial support for many of these practices through cost-sharing; incentive, maintenance, and rental payments; and producer grants (Table 1, and USDA National Agroforestry Center 2003). Additional federal and state programs support the installation and management of these working tree practices. The public's growing awareness of these practices and the multiple services they can provide on private lands translates into greater support for regional programs like the multi-state Chesapeake Bay, the White Water to Blue Water, and the Green Lands to Blue Water water quality initiatives.

Why do we need to account for working trees?

Despite addressing concerns like water quality and greenhouse gas emissions, working tree plantings are largely unknown to many who are responsible for developing or influencing natural resource investment directions. Agroforestry, by definition, straddles the agricultural and forestry sectors, but often is not advocated by either one. The agronomic sector views agroforestry as forestry since trees are involved; the forestry sector categorizes these practices as agriculture since land use is not changed by their addition. This ambiguity causes problems as new natural resource policies and programs are developed. Carbon sequestration efforts, for example, have largely focused on adaptive management of existing forests and conservation tillage of croplands. Many farmaccounting models and tools ignore tree-based practices as viable carbon sequestering options. The new

Table 1 USDA programs supporting agroforestry practices (adapted from Godsey 2003)

\begin{tabular}{|c|c|c|c|c|c|}
\hline \multirow[t]{2}{*}{ Program } & \multicolumn{5}{|c|}{ Agroforestry practice } \\
\hline & Alley cropping & Riparian buffer & Windbreak & Silvo-pasture & $\begin{array}{l}\text { Forest } \\
\text { farming }\end{array}$ \\
\hline Conservation Reserve Program (CRP) & $\mathrm{C} / \mathrm{M} / \mathrm{R}$ & & & & \\
\hline Continuous CRP (CCRP) & & $\mathrm{C} / \mathrm{I} / \mathrm{M} / \mathrm{R}$ & $\mathrm{C} / \mathrm{I} / \mathrm{M} / \mathrm{R}$ & & \\
\hline Conservation Reserve Enhancement Program (CREP) & & $\mathrm{C} / \mathrm{I} / \mathrm{M} / \mathrm{R}$ & & & \\
\hline Environmental Quality Incentive Program (EQIP) & $\mathrm{C} / \mathrm{I}$ & $\mathrm{C} / \mathrm{I}$ & $\mathrm{C} / \mathrm{I}$ & $\mathrm{C}$ & $\mathrm{C}$ \\
\hline Wetlands Reserve Program (WRP) & & $\mathrm{C} / \mathrm{R}$ & & & \\
\hline Conservation Security Program (CSP) & $\mathrm{C} / \mathrm{R}$ & $\mathrm{C} / \mathrm{R}$ & $\mathrm{C} / \mathrm{R}$ & $\mathrm{C} / \mathrm{R}$ & \\
\hline Forest Land Enhancement Program (FLEP) & $\mathrm{C}$ & $\mathrm{C}$ & $\mathrm{C}$ & $\mathrm{C}$ & $\mathrm{C}$ \\
\hline Sustainable Agriculture Research \& Education (SARE) & PG & PG & PG & PG & PG \\
\hline
\end{tabular}

C, Cost share; I, incentive; M, maintenance; PG, producer grant; R, rental 
Voluntary Reporting of Greenhouse Gases-Carbon Management Evaluation Tool (COMET-VR) (http:// www.cometvr.colostate.edu) calculates agriculturesector carbon sequestration in the soil from shifts in cultivation, grazing, and other non-tree-based practices. COMET-VR thus inadvertently promotes nontree based management options as the primary carbon sequestering practices for the agricultural sector. A similar observation applies to the promising bioenergy discussions; again, tree-based practices are often ignored despite having highly favorable net energy ratios, the ability to be produced on marginal farmland, and the capability to simultaneously provide a wide range of conservation benefits (Gallagher 2006; Ruark et al. 2006). Information on the location, species composition, and age of these systems would serve to identify the potential for developing a woody-based biorefinery or for augmenting a cropbased system.

Community forests, agroforestry plantings, and other conservation plantings in the Midwest are dominated by Scots pine (Pinus sylvestris), green ash (Fraxinus pennsylvanica), and oak (Quercus spp.). These species are susceptible to pine wilt nematode (Bursaphelenchus xylophilus), emerald ash borer (Agrilus planipennis), and Sudden Oak Death (caused by Phytophthora ramorum), respectively. However, the lack of inventory data, especially species distribution in these plantings and the occurrence of pests and diseases, makes it difficult to assess the health risks and threats to working tree plantings.

\section{What is FIA?}

For more than 75 years, the USDA Forest Service Forest Inventory and Analysis (FIA) program has been charged by Congress to "make and keep current a comprehensive inventory and analysis of the present and prospective conditions of and requirements for the renewable resources of the forest and rangelands of the United States" (McSweeney-McNary Act of 1928). FIA is the primary source for information about the extent, condition, status, and trends of the forest resource across all ownerships in the United States (Smith 2002). FIA traditionally concentrated on the nation's timber resources, but a change in focus was codified by the passage of the Agricultural Research, Extension and Education Reform Act of 1998, integrating FIA with the Forest Health Monitoring program. Annual FIA inventories are underway or completed in 45 of the 50 states, and the data are critical to state, national, and international assessments (Smith 2002; Stolte et al. 2002). The contributions from working trees could be well-estimated by a comprehensive inventory like FIA, but the trees used in agroforestry practices are not explicitly inventoried because of historical definitions of forest land.

In this context, our study had three objectives: (1) to estimate the area of working trees in the Midwest (Illinois, Indiana, Iowa, Kansas, Michigan, Minnesota, Missouri, Nebraska, North Dakota, South Dakota, and Wisconsin) using FIA data; (2) to estimate the area of working trees in the Midwest using MODIS (the MODerate Resolution Imaging Spectroradiometer) Vegetation Continuous Fields (VCF); and (3) to propose improved methods for working tree inventories.

\section{Methods and data}

\section{FIA inventory}

FIA applies a nationally consistent sampling protocol using a quasi-systematic design covering all ownerships in the US (Brand et al. 2000). This sampling design is based on an array of hexagons assigned to separate interpenetrating, non-overlapping annual sampling panels (Brand et al. 2000; Fig. 1). Each hexagon represents approximately 2,403 ha (5,937 acres), and plots in two adjacent hexagons are not measured during the same year (Brand et al. 2000). Permanent fixed-area plots are installed in each hexagon, and tree measurements (e.g., species, height, and diameter) are taken on four subplots (Fig. 2) where they meet the definition of forest land provided below:

“(a) the condition is at least 10-percent stocked by trees ... of any size or has been at least 10percent stocked in the past. Additionally, the condition is not subject to nonforest use(s) that prevent normal tree regeneration and succession such as regular mowing, intensive grazing, or recreation activities; or

"(b) in several western woodland species ... where stocking cannot be determined, and the condition has at least 5 percent crown cover by 


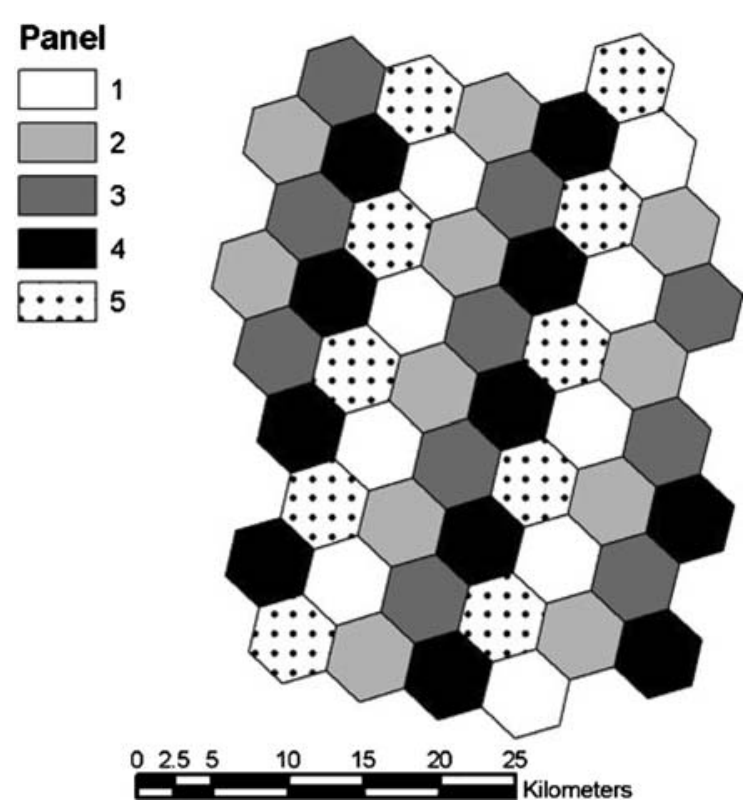

Fig. 1 Forest Inventory and Analysis (FIA) sampling design. At least one FIA plot is installed in each hexagon, provided the plot meets the definition of forest land. One panel is sampled each year, and all panels are completed after 5 years

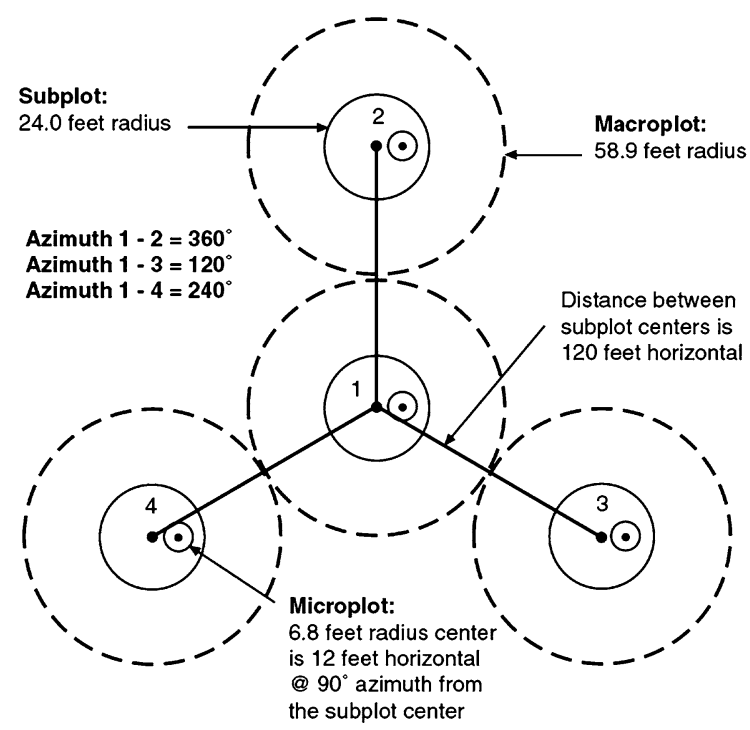

Fig. 2 FIA plot design (source: Bechtold and Scott 2005). One foot $=0.3048 \mathrm{~m}$

trees of any size, or has had at least 5 percent cover in the past. Additionally, the condition is not subject to nonforest use that prevents normal regeneration and succession such as regular mowing, chaining, or recreation activities." (USDA Forest Service 2004)
Further, the condition generally must be at least $36.6 \mathrm{~m}$ wide and 0.40 ha in area to qualify as forest land (USDA Forest Service 2004; Fig. 3). Additional forest health measurements (crown condition, damage, down woody material, lichens, ownership, ozone, soils, and vegetation diversity and structure) are taken at a systematic subsample of $6.25 \%$ of these plots (USDA Forest Service 2004).

FIA inventories are designed to determine the area of forest land and the volume of woody biomass. Specific land use categories are applied that combine forest cover with land use (Table 2); other regions use different, but similar, categories reflecting land use activities within their region.

Crosswalk tables between agroforestry practices and the inventory's land use classifications were developed by reviewing current inventory protocols (USDA Forest Service 2004) in consultation with inventory personnel. FIA inventories do not incorporate accepted definitions of agroforestry practices as such; working trees are distributed among many different possible land use codes related more to the amount of trees than to agroforestry definitions (Table 3). Using this information, the extent of each land use/land cover was calculated with queries to inventory databases.

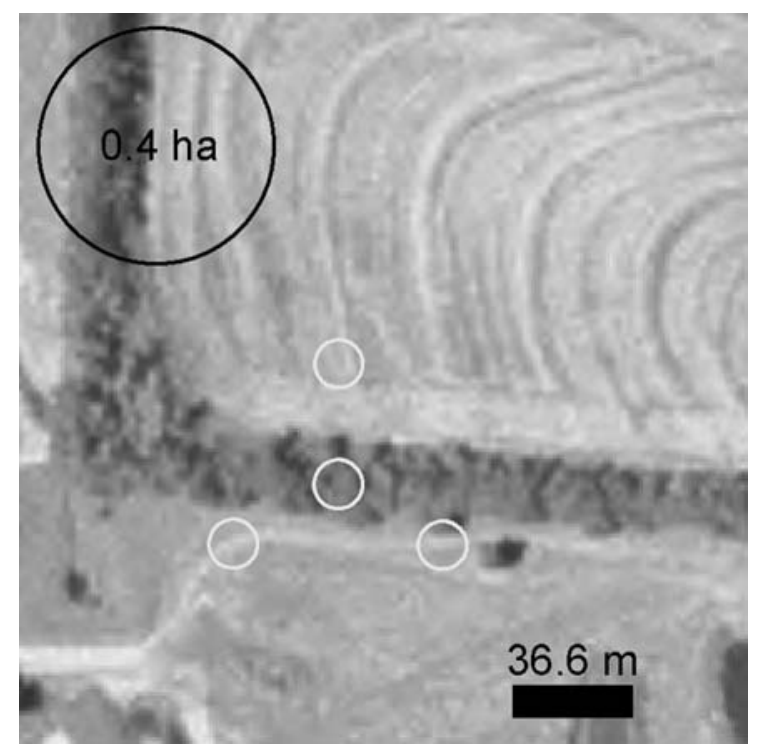

Fig. 3 The FIA circular plot design shown against a background with a linear planting of working trees. In this case, the planting does not meet the minimum width requirement for forest land 
Table 2 Land-use categories used by the North Central FIA program (NCFIA) which include working trees. Only trees on accessible forest land are measured (adapted from USDA Forest Service 2004)

Category $\quad$ NCLU $^{\mathrm{a}}$ Definition

Accessible forest land

Timberland

Pastured timberland 21

Plantations

Wide windbreaks

Wooded pasture

Urban forest land
Forest land that is capable of producing in excess of 1.4 cubic meters per hectare per year of roundwood products, excluding fuelwood, and is not withdrawn from timber utilization by statute, administrative designation, or exclusive use for Christmas tree production. (If land is used for grazing, see codes 21 and 59.)

Forest land used for wood production and grazing. (If land has a stocking value of less than 10 in trees over $2.5 \mathrm{~cm} \mathrm{DBH}$ or less than 25 in growing-stock trees of any size, see codes 52 and 59.)

An artificially reforested area, sufficiently productive to qualify as commercial forest land, established by planting or by direct seeding. Planted species are not necessarily predominant. The forest type, stand age, and stand size class should reflect the planted species. If the plantation has failed, give the plot a GLU code 20. Unless the land is used primarily for grazing, code 22 is preferred over codes 21 and 59.

A group of trees, greater than $36.6 \mathrm{~m}$ wide and 0.4 ha in size, protecting buildings in use. Area would qualify as timberland except that the primary land use is protection of buildings. As a guideline, consider using code 22 if there are more than 12 rows of trees or the area is larger than 2 ha.

Grazed land with a stocking value of more than 10.0 in all live trees $2.5 \mathrm{~cm}$ DBH or larger, but less than 25.0 in growing stock (20 class) trees of any size. Two situations are possible. The first is that the land could qualify as pastured timberland except that the low stocking in growing stock trees indicates that the land is not being used for wood production. The second is that the land is unproductive for timber, due to livestock or intrinsic site factors, and is being used for forage. If evidence indicates that the primary use is wood production or the protection of buildings see code 21 and 57.

Land that normally would meet the criteria for timberland, but is in an urban-suburban area surrounded by commercial, industrial, or residential development. It is extremely unlikely that such land is used for timber products on a continuing basis. Example: wooded creek bottom surrounded by houses.

Cropland with scattered inclusions of single trees or small groups of trees. Orchards are also included in this class.

Land used for grazing with a stocking value of less than 10.0 in all live trees $2.5 \mathrm{~cm}$ DBH or larger.

A block of continuous forest land ( $>0.4$ ha) that meets the definition of forest land (code 20, 21, $22,40,41,45)$ except that it is less than $36.6 \mathrm{~m}$ wide.

A group of trees, less than $36.6 \mathrm{~m}$ wide, used for the protection of buildings in use.

A group of trees, less than $36.6 \mathrm{~m}$ wide, used for the protection of soil and crop fields.

Area with trees that is developed for residential, industrial, recreational, or other urban use. For example city park, cemetery, golf course, maintained backyard, farmsteads with trees. The $36.6 \mathrm{~m}, 0.4$ ha rule does not apply in the case of a maintained yard.

${ }^{a}$ NCFIA land use code

b These land uses must have one or more trees, $13 \mathrm{~cm}$ DBH or larger, within the visual 0.4 ha surrounding the plot center

\section{MODIS Vegetation Continuous Field (VCF)}

Although aerial photography provides adequate information to identify groups of working trees (e.g., windbreaks and shelterbelts), assessment over a large area can require substantial photo interpretation time. Satellite-based estimation provides the opportunity to assess working trees in a far less labor-intensive manner.
VCF is a global dataset derived from MODIS satellite imagery, consisting of three layers representing percent tree cover, percent herbaceous cover and percent bare ground cover (Hansen et al. 2002). Data can be obtained from the University of Maryland Global Land Cover Facility (http://www.glcf.umiacs. umd.edu/data/vcf/index.shtml). The VCF dataset was created at 500-m resolution, a size which is coarse 


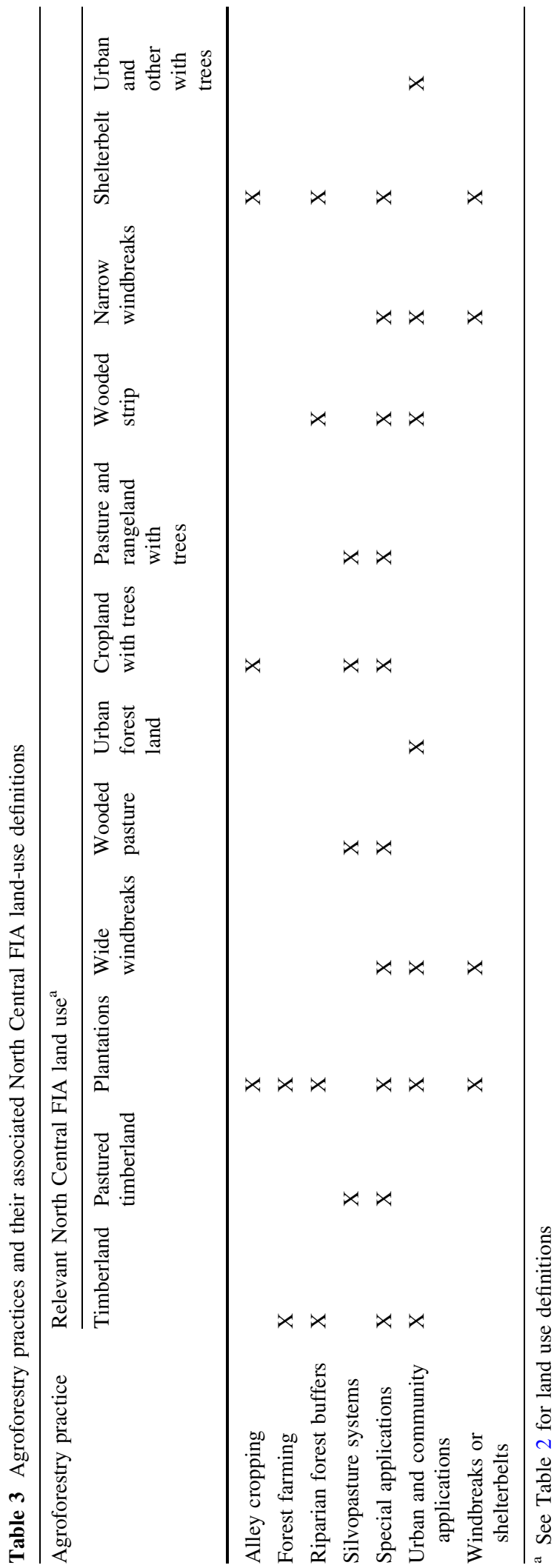

relative to tree plantings in agricultural landscapes. Other data products, such as the National Land Cover Dataset, are collected at a finer scale, but contain no land cover classes explicitly for agroforestry, and significant classification errors in both forestry and agricultural classes are documented (Vogelman et al. 2001). For assessing non-forest trees, the VCF dataset offers the attractive feature of providing an estimate, even for pixels only partially occupied by trees.

The mean VCF percent tree cover in FIA survey units (Fig. 4) for six states (North Dakota, South Dakota, Nebraska, Kansas, Iowa, and Missouri) was used to determine the area of land with tree cover. These numbers were then compared to treed land area calculated from FIA plot information for the same survey units.

\section{Results and discussion}

How extensive are working trees?

A review of recent FIA inventories of the Midwest demonstrates the challenges that FIA faces when estimating the area of working trees in the landscape. FIA estimates indicate that the treed land of many states is dominated by timberland, but sizable areas of other land uses exist. Pastured timberland, wooded pasture, and pasture and rangeland with trees range between approximately $1 \%$ of total treed land in

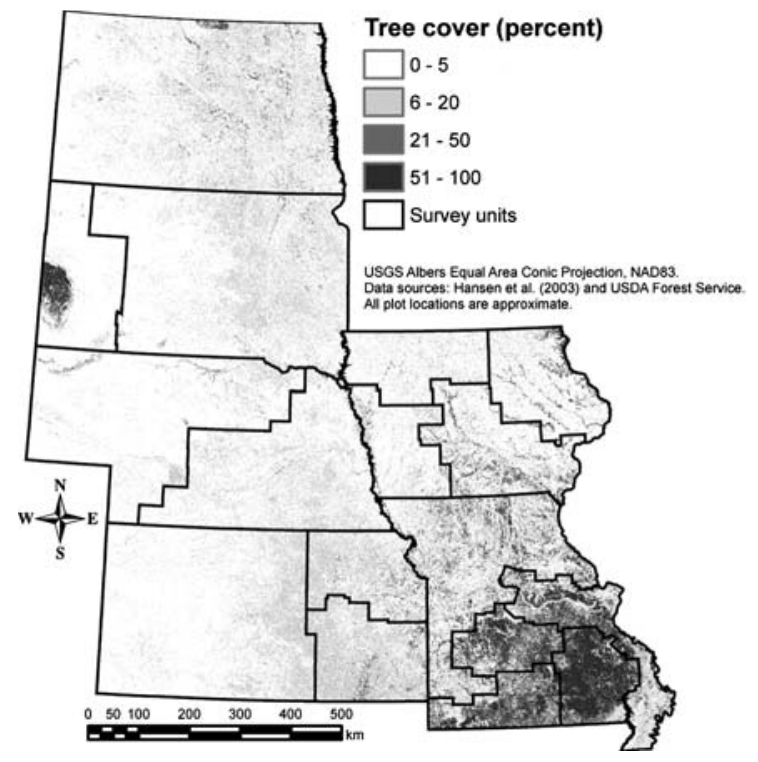

Fig. 4 FIA survey units in North Dakota, South Dakota, Nebraska, Kansas, Iowa, and Missouri 
Michigan to more than $50 \%$ in Nebraska, and this percentage generally increases from east to west across the region (Table 4). All of this land is not definitively silvopasture, but this area still represents a large proportion of the landscape, particularly in the Dakotas, Kansas, and Nebraska. Narrow windbreaks and shelterbelts, neither inventoried by FIA, were seven times as common as the inventoried wide windbreaks (Table 4). Gaps exist in the FIA inventories of working trees, and the percentage of nonforest land with trees generally increases as we move west across the region (Table 4; Fig. 5).

Conclusive statements cannot be made about the extent of working trees from the inventory, but the data suggest widespread working tree practices, particularly pasture- and windbreak-affiliated land uses. Aside from these general statements, no additional inventory information is available.

What does MODIS VCF tell us about working trees?

Traditional aerial photo interpretation methods have been used to assess working trees. For example, Hartong and Moessner (1956) estimated Iowa's reported timber area would have been $25 \%$ greater

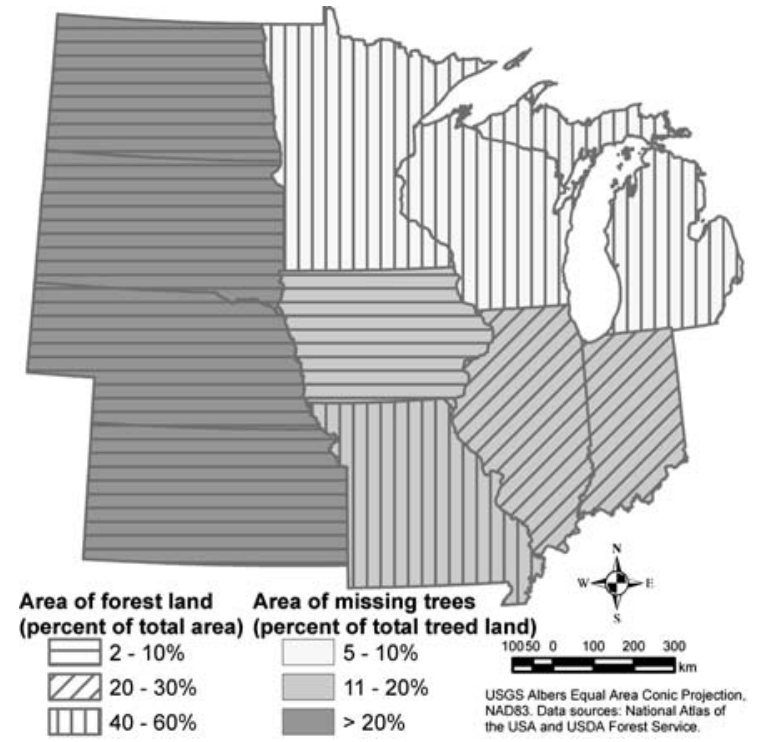

Fig. 5 Forest land and missing tree fractions derived from FIA data. Missing tree fraction is determined by comparing FIA forest land area estimates with MODIS VCF estimates of tree canopy cover

had field measurements included working trees. Hansen (1985) used line intersect sampling in conjunction with aerial photography and determined that wooded strips occupy 136,100 ha in Kansas. If

Table 4 FIA estimates of the area of distinct land uses that may include working trees

\begin{tabular}{|c|c|c|c|c|c|c|c|c|c|c|c|}
\hline \multirow[t]{2}{*}{ Land use } & \multicolumn{11}{|c|}{ Thousands of hectares } \\
\hline & IL & IN & IA & $\mathrm{KS}$ & MI & $\mathrm{MN}$ & MO & $\mathrm{NE}$ & ND & SD & WI \\
\hline \multicolumn{12}{|l|}{ Accessible forest land } \\
\hline Timberland & 1,544 & 1,595 & 809 & 534 & 7,115 & 5,725 & 4,803 & 193 & 151 & 426 & 5,873 \\
\hline Pastured Timberland & 113 & 90 & 244 & 221 & 26 & 111 & 797 & 254 & 73 & 108 & 154 \\
\hline Plantations & 27 & 61 & 2 & 6 & 440 & 173 & 14 & 7 & 3 & Nil & 338 \\
\hline Wide windbreaks $(>36.6 \mathrm{~m})$ & Nil & Nil & 3 & 10 & Nil & 7 & Nil & 11 & 4 & 5 & Nil \\
\hline Wooded pasture & 26 & 12 & 33 & 75 & 4 & 40 & 127 & 32 & 45 & 102 & 27 \\
\hline Urban forest land & 13 & 49 & 9 & 5 & 60 & 22 & 39 & 3 & Nil & 1 & 19 \\
\hline \multicolumn{12}{|l|}{ Non-forest land with trees } \\
\hline Cropland with trees & 18 & 8 & 7 & 10 & 102 & 35 & 100 & 8 & 6 & Nil & 21 \\
\hline Pasture and rangeland with trees & 56 & 58 & 91 & 125 & 25 & 72 & 383 & 63 & 68 & 171 & 40 \\
\hline Wooded strip & 50 & 18 & 74 & 46 & 27 & 44 & 144 & 23 & 17 & 16 & 22 \\
\hline Narrow windbreak $(<36.6 \mathrm{~m})$ & 6 & Nil & 2 & 15 & 2 & 12 & 4 & 27 & 12 & 38 & 4 \\
\hline Shelterbelt & Nil & Nil & Nil & 19 & 13 & 8 & 5 & 15 & 57 & 15 & 17 \\
\hline Urban and other with trees & 178 & 190 & 80 & 70 & 443 & 277 & 257 & 40 & 12 & 32 & 220 \\
\hline Total treed land & 2,031 & 2,081 & 1,354 & 1,136 & 8,257 & 6,526 & 6,673 & 676 & 448 & 914 & 6,735 \\
\hline Percent non-inventoried "forest" & 15 & 13 & 19 & 25 & 7 & 7 & 13 & 26 & 38 & 30 & 5 \\
\hline
\end{tabular}

Data are taken from the 2000 to 2004 inventories 
we assume this land use would currently include all linear features, Hansen's (1985) estimate is still greater than current estimates of those features and fully $12 \%$ of current estimates of treed-land in Kansas (Table 4).

The VCF estimate of land area with tree cover is higher than the FIA estimate of treed land in lessdensely forested units and slightly lower in those units with more forest (Table 5; Fig. 6). When we consider the uncertainty in the FIA unit-level estimates (Table 5), the two methods produce significantly different estimates $(\alpha=0.05)$ in Missouri, North Dakota, South Dakota, Nebraska, and Kansas. Areas with less treed land tend to have higher uncertainty. From an all-tree inventory perspective, uncertainty is compounded in lightly forested areas because there are few forested plots and agricultural tree plantings are under-represented.

In Fig. 7, the pixel counts of VCF percent tree cover are shown for North Dakota, South Dakota, Nebraska, and Kansas, sparsely forested states with large numbers of non-forest trees. Large numbers of pixels are occupied by relatively low tree cover; for example, percent tree cover from 1 to $17 \%$ occurs on at least 10,000 pixels each. If we assume that these pixels with sparse tree cover include areas of working trees and that the median value is $9 \%$ tree cover for each of the 10,000 pixels, we conservatively estimate approximately 400,000 ha of non-forest tree cover in these four states $(25 \mathrm{ha} /$ pixel $\times 17$ classes $\times 10,000$ pixels/class $\times 0.09=382,500$ ha).

As with the analysis of FIA inventory data (Table 4), it is difficult to draw conclusions about the VCF analysis in this study. Estimates of percent tree cover for a particular pixel have a significant and unknown level of uncertainty, particularly when a small proportion of the $500-\mathrm{m}$ pixel is occupied by tree cover (i.e., the percent tree cover is low). We present the VCF data here to reinforce the idea that, given the areal extent of non-forest tree cover, a sizable information gap exists; valuable data on species distribution and health can be obtained only with additional inventory plots.

What are the obstacles to an inventory of working trees?

Land with working trees is a subset of all land with trees. Agroforestry is distinguished from traditional forestry by its association with an agricultural or forage crop (USDA Natural Resources Conservation Service 1996). The definition of agroforestry also specifies that these plantings are deliberately composed, arranged, and managed to enhance or restore key ecological services (USDA Natural Resources Conservation Service 1996). Woody encroachment on rangelands used for grazing would not be considered working trees. Orchards and Christmas tree plantations are not generally established to enhance or restore key ecological services, so they also would not be considered working trees.

FIA applies a strict definition of land use. The FIA program is implemented nationally, and definitions are critical to collecting data that can be integrated at that level. Because of historic practices, land use is classified in a manner that does not match agroforestry practices on a one-to-one basis. In general, the assignment of a specific land use code will account for, in order of preference, the size of the stand, the size and number of trees (stocking), and the observed evidence of past and present land management. For example, trees obviously established artificially would be classified as a plantation if the stand was large enough to meet the definition of forest land. The same planting would be classified as a wide windbreak if it protected buildings; this is common problem in many applications separating land cover from land use. Agroforestry specialists may classify working tree plantings as riparian forest buffers if they are adjacent to a water body, but the inventory does not specify any riparian land uses. Smaller plantings that do no meet the forest land definition could be classified as narrow windbreaks (protecting buildings) or shelterbelts (protecting cropland). Similarly, an active pasture with trees (silvopasture in the agroforestry community) would be classified as pastured timberland if it met the size and stocking requirements for forest land. Fewer trees would yield a classification of wooded pasture. As the number of trees and the size of the stand continued to decline, the classification would grade into pasture and rangeland with trees.

Perhaps most importantly, the public and elected decision-makers have not advocated an inventory of working trees. The FIA mandate has focused on more traditional resources, so sufficient funding and personnel are not allocated to measure agroforestry systems at present. The obstacles to a more 
Table 5 A comparison of VCF estimates of tree cover with FIA estimates of forest area a Including reserved land and other land uses without working trees

Estimates are shown for inventory units in Iowa, Kansas, Missouri, Nebraska, North Dakota, and South Dakota

\begin{tabular}{|c|c|c|c|c|}
\hline Inventory unit & $\begin{array}{l}\text { VCF estimate, } \\
\text { thousand ha }\end{array}$ & $\begin{array}{l}\text { FIA estimate, } \\
\text { thousand ha }\end{array}$ & $\begin{array}{l}\text { SE of FIA } \\
\text { estimate, \% }\end{array}$ & $\begin{array}{l}\text { Number of } \\
\text { forested FIA plots }\end{array}$ \\
\hline \multicolumn{5}{|l|}{ Iowa } \\
\hline Northwestern & 121 & 64 & 17.73 & 35 \\
\hline Northeastern & 299 & 450 & 4.49 & 219 \\
\hline Southwestern & 149 & 202 & 8.79 & 108 \\
\hline Southeastern & 457 & 675 & 3.51 & 313 \\
\hline \multicolumn{5}{|l|}{ Kansas } \\
\hline Northeastern unit & 459 & 493 & 5.62 & 192 \\
\hline Southeastern unit & 510 & 416 & 6.35 & 151 \\
\hline Western unit & 680 & 255 & 9.28 & 110 \\
\hline \multicolumn{5}{|l|}{ Missouri } \\
\hline Eastern Ozarks unit & 1,671 & 1,822 & 1.29 & 1,380 \\
\hline Southwest Ozarks unit & 1,031 & 1,260 & 2.03 & 618 \\
\hline Northwest Ozarks unit & 999 & 1,124 & 1.98 & 516 \\
\hline Prairie unit & 1,385 & 1,610 & 2.19 & 772 \\
\hline Riverborder unit & 1,116 & 1,066 & 2.08 & 859 \\
\hline \multicolumn{5}{|l|}{ Nebraska } \\
\hline Eastern unit & 599 & 352 & 7.73 & 140 \\
\hline Western unit & 493 & 334 & 7.34 & 129 \\
\hline \multicolumn{5}{|l|}{ North Dakota } \\
\hline Eastern unit & 2304 & 482 & 6.92 & 192 \\
\hline \multicolumn{5}{|l|}{ South Dakota } \\
\hline Eastern unit & 1,744 & 292 & 9.21 & 109 \\
\hline Western unit & 437 & 644 & 3.95 & 226 \\
\hline
\end{tabular}

comprehensive inventory are definition-oriented and thus tied directly to the original purpose of the FIA program.

A proposal for an improved working tree inventory

It is possible to capitalize on the strengths of FIA to improve the inventory of working trees. FIA conducts inventories only on accessible forest land. Since any one agroforestry practice could occur in either accessible forest land or non-forest land with trees (Table 4), FIA does not currently estimate the area or volume of woody biomass in specific agroforestry systems. One simple change would be to measure trees on every plot whether the condition meets the definition of forest land or not-an all-tree inventory. Within the inventory, there were several land use categories similar to standard agroforestry definitions, but a new data element could be collected in the field that actually specifies agroforestry practices. FIA could thus provide estimates of working tree volume by land use nationwide. A pilot study is being developed to improve FIA inventories of windbreaks, shelterbelts, and riparian tree resources (D. Haugen pers. comm. 2005), and the Interior West FIA unit is testing the utility of high-resolution aerial photography.

The combination of current FIA volume estimates with improved estimates of spatial extent would provide unit area estimates of biomass in working trees. Such an effort may not completely fulfill the needs of the agroforestry community, but it would be one step closer to an inventory of working trees.

\section{Conclusions}

The growing interest in working trees is an excellent example of how some of the most challenging management decisions occur at the interface between disciplines. The FIA program has a mandate to conduct national inventories of forest land and forest 


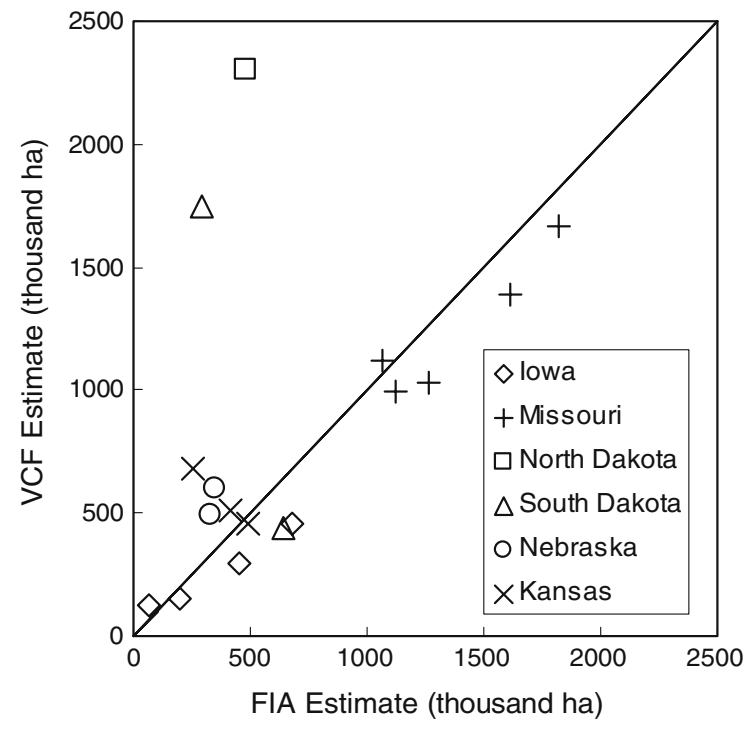

Fig. 6 MODIS VCF tree cover compared to FIA estimates of treed land by state inventory unit

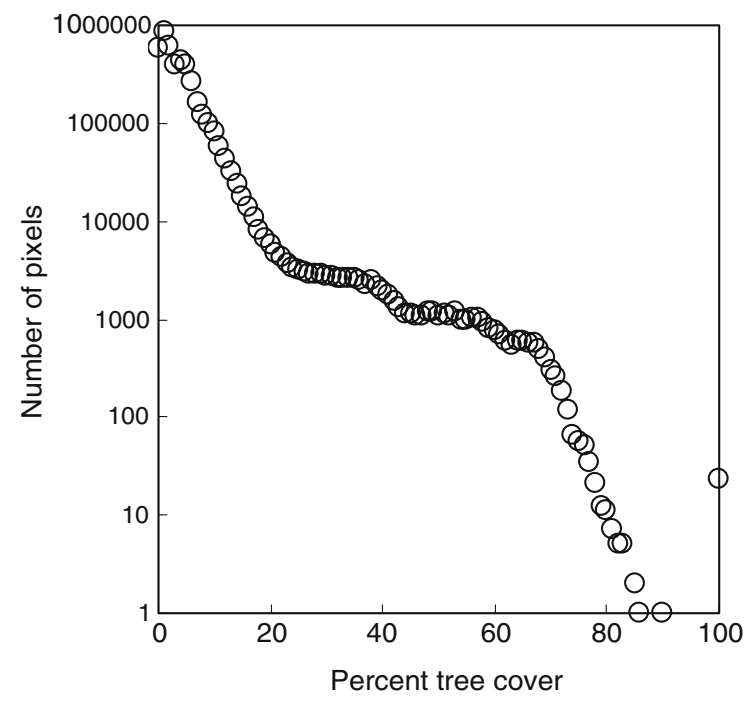

Fig. 7 Histogram of MODIS percent tree cover estimates for Kansas, Nebraska, North Dakota, and South Dakota. The number of pixels is plotted against a logarithmic scale to emphasize the large area with less than $20 \%$ tree cover

soil. Unfortunately, FIA is not particularly effective at providing relevant information to the agroforestry community. The program has historically focused on traditional forestry resources. The definition of forest land emphasizes forestry land uses. However, a review of woody resources in 11 Midwestern states suggests that substantial areas of working trees are not inventoried. FIA's pre-field work suggests that an inventory of all working trees in these states would require an increase in effort (i.e., funding) ranging from $4 \%$ in Minnesota to $50 \%$ in North Dakota; the mean increase across all 11 states is $7 \%$. In practice this collaboration would require FIA crews to visit every plot with trees, regardless of land use, and conservation land uses would need to be consistently identified. The necessary investment is not small, but minor modifications to the program would facilitate an effective inventory of the country's working trees. The resulting information would prove valuable to managers and decision-makers confronted with significant environmental issues across the nation's working lands.

Acknowledgements The authors would like to thank the following individuals for their comments on this and earlier versions of the manuscript: D. Coble, Stephen F. Austin State University; T. Morgan, University of Montana; J. Blehm, W. Burkman, R. Czaplewski, M. Hatfield, D. Haugen, R. McRoberts, R. Piva, USDA Forest Service; and J. Goebel, V. Lessard, B. Wight and D. Williams, USDA Natural Resources Conservation Service.

\section{References}

Bechtold WA, Scott CT (2005) The forest inventory and analysis plot design. In: Bechtold WA, Patterson PL (eds) The enhanced forest inventory and analysis program: national sampling design and estimation procedures. Gen Tech Rep SRS-80. USDA Forest Service, Asheville, NC, pp $27-42$

Brand GJ, Nelson MD, Wendt DG, Nimerfro KK (2000) The hexagon/panel system for selecting FIA plots under and annual inventory. In: McRoberts RE, Reams GA, Van Deusen PC (eds) Proceedings of the first annual forest inventory and analysis symposium. Gen Tech Rep NC213. USDA Forest Service, St. Paul, MN, pp 8-13

Gallagher PW (2006) Energy production with biomass: what are the prospects? Choices 21:21-26

Godsey L (2003) Funding incentives for agroforestry in Missouri. 5-2002. University of Missouri Center for Agroforestry, Columbia, MO. Available online at http://www. centerforagroforestry.org/pubs/fundincent.pdf. Cited 15 March 2008

Guo Q (2000) Climate change and biodiversity conservation in Great Plains agroecosystems. Glob Environ Change 10:289-298

Hansen M (1985) Line intersect sampling of wooded strips. For Sci 31(2):282-288

Hansen M, DeFries R, Townshend JRG et al (2002) Towards an operational MODIS continuous field of percent tree cover algorithm: examples using AVHRR and MODIS. Rem Sens Environ 83:303-319 
Hansen M, DeFries R, Townshend JR, Carroll M, Dimiceli C, Sohlberg R (2003) 500 m MODIS vegetation continuous fields. Global Land Cover Facility, College Park, MD

Hartong AL, Moessner KE (1956) Wooded strips in Iowa. Forest Survey Release 21. USDA Central States Forest Experiment Station, Columbus, $\mathrm{OH}$

National Research Council (1993) Soil and water quality: an agenda for agriculture. National Academy Press, Washington, DC

National Research Council (2002) Riparian areas: functions and strategies for management. National Academy Press, Washington, DC

Olson R, Schoeneberger MM, Aschmann S (2000) An ecological foundation for temperate agroforestry. In: Garrett HE, Rietveld WJ, Fisher RF (eds) North American agroforestry: an integrated science and practice. American Society of Agronomy, Madison, WI, pp 31-61

Ruark G, Josiah S, Riemenschneider D, Volk T (2006) Perennial crops for bio-fuels and conservation. Paper presented at 2006 USDA Agricultural Outlook Forum, Prospering In Rural America, Arlington, VA, 16 Feb 2006 [On-line] Available at http://www.usda.gov/oce/forum/2006\%20 Speeches/PDF\%20speech\%20docs/Ruark2806.pdf. Cited 15 March 2008

Schoeneberger MM (2005) Agroforestry: working trees for sequestering carbon on ag lands. In: Brooks KN, Ffolliott PF (eds) Moving agroforestry into the mainstream. Proceedings of the 9th North American agroforestry conference, Rochester, MN, 12-15 June 2005 [CD-ROM]. Dept. Forest Resources, Univ. Minnesota, St. Paul, MN, $13 \mathrm{pp}$

Schoeneberger MM, Bentrup G, Francis CF (2001) Ecobelts: reconnecting agriculture and communities. In: Flora $\mathrm{C}$ (ed) Interactions between agroecosystems and rural human communities. CRC Press, Boca Raton, FL, pp 239-260

Smith WB (2002) Forest inventory and analysis: a national inventory and monitoring program. Environ Pollut 116:S233-S242

Stolte K, Conkling B, Campbell S, Gillespie A (2002) Forest health indicators: forest inventory and analysis program. FS-746. USDA Forest Service, Washington, DC

USDA Forest Service (2004) Forest inventory and analysis national core field guide. vol 1: field data collection procedures for phase 2 plots, version 3.0 [Online]. USDA Forest Service, St. Paul, MN. Available at www. fia.fs.fed.us/library/field-guides-methods-proc. Cited 15 March 2008

USDA National Agroforestry Center (2003) Incentives for agroforestry: 2002 Farm Bill. In: Inside Agroforestry [Online]. USDA National Agroforestry Center, Lincoln, NE. Available at www.unl.edu/nac/ia/winter03/winter03.pdf. Cited 15 March 2008

USDA National Agroforestry Center (2004) Working trees for water quality [Online]. USDA Forest Service and USDA Natural Resources Conservation Service, Lincoln, NE. Available at www.unl.edu/nac/brochures/wtwq/wtwq.pdf. Cited 15 March 2008

USDA Natural Resources Conservation Service (1996) Agroforestry for farms and ranches. Agroforestry Technical Note No. 1 [Online]. USDA Natural Resources Conservation Service, Lincoln, NE. Available at www.nrcs.usda.gov/ technical/ECS/forest/technote.html. Cited 15 March 2008

Vogelman JE, Howard SM, Yang L, Larson CR, Wylie BK, Driel NV (2001) Completion of the 1990s National Land Cover Data Set for the conterminous United States from Landsat Thematic Mapper data and ancillary data sources. Photogramm Eng Rem Sens 67:650-662 